\title{
Penilaian Tingkat Kerentanan Bangunan Gedung Di Area Sekolah SIT Aliya Bogor
}

\author{
Building Vulnerability Assessment in School Area of SIT Aliya \\ Bogor
}

\author{
Muhamad Lutfi ${ }^{1, a)}$ \& Rafitri Suryawani ${ }^{1, b)}$ \\ ${ }^{1)}$ Program Studi Teknik Sipil, Fakultas Teknik dan Sains, Universitas Ibn Khaldun, Bogor.
}

Koresponden : ${ }^{a}$ lutfim97@gmail.com \& ${ }^{b}$ rafitrisuryawani@gmail.com

\begin{abstract}
ABSTRAK
Wilayah Kota Bogor memiliki potensi bencana alam diantaranya tanah longsor, pohon tumbang, bangunan ambruk, kebakaran, banjir, angin puting beliung, dan gempa bumi. Sering kali ditemukan bangunan sekolah didirikan di area yang berpotensi bencana alam. SIT Aliya Bogor dibangun dengan kondisi kearah vertikal sebagai upaya optimalisasi lahan yang semakin terbatas. Maka perlu dilakukan penilaian untuk mengetahui tingkat kerentanan bangunan sekolah terhadap bencana gempa dengan menggunakan Metode Rapid Visual Screening (RVS) dan Metode Hazus. Formulir RVS didapatkan dari desain spectra dan respon spectrum, yaitu level moderarately high seismicity berdasarkan koordinat bangunan. Dari hasil $R V S$ didapatkan nilai kerentanan bangunan SIT Aliya Bogor sebesar 0,083\% dengan mendapatkan nilai rata-rata 3,083. Dari 6 gedung 1 gedung memiliki vertical irregularity dan plan irregularity, 3 gedung memiliki vertical irregularity, 2 gedung tidak memiliki penyimpangan dengan tipe bangunan $\mathrm{C} 1$ dan tanah diasumsikan tanah sedang (tipe D) karena tidak ada penyelidikan tanah pada lokasi tersebut. Dan hasil Metode Hazus, probabilitas kerentanan bangunan yang didapatkan sebesar 6,1923\% dengan nilai $\mathrm{Sd}=0,065$. Moderate - code seismic design level direncanakan pada seismic design level dan tipe bangunan $\mathrm{C} 1 \mathrm{M}$ disamakan dengan RVS. Secara keseluruhan bangunan sekolah memiliki potensi kerentanan terhadap gempa.
\end{abstract}

Kata Kunci : manajemen infrastruktur, evaluasi bangunan, kerentanan bangunan, gempa, RVS, FEMA P-154, HAZUS-MH MR4.

\section{PENDAHULUAN}

Sebagian besar wilayah Kota Bogor memiliki kontur yang cukup bervariasi dan curah hujan yang sangat tinggi. Maka potensi bencana alam yang sering terjadi diantaranya adalah tanah longsor, pohon tumbang, bangunan ambruk, kebakaran, banjir, angin puting beliung, dan gempa bumi (BPBD Kota Bogor, 2019). Di Kota Bogor sering kali ditemukan bangunan sekolah didirikan di areal berpotensi bencana alam.

Gedung sekolah SIT Aliya Bogor berlokasi di Jl. Gardu Raya, RT.03/RW.11, Bubulak, Kec. Bogor Barat Kota Bogor, Jawa Barat 16115. Sebelah utara berbatasan dengan permukiman warga, sebelah timur berbatasan dengan Sungai Cisindang Barang dan permukiman warga, sebelah barat berbatasan dengan permukiman warga dan sebelah selatan berbatasan dengan Jl. Raya Dramaga - Bogor. Gedung sekolah SIT Aliya Bogor dibangun berorientasi vertikal sebagai upaya optimalisasi akibat semakin terbatasnya lahan sehingga kajian struktur akan menjadi kompleks dengan kondisi geografis Kota Bogor. 
Infrastrultur Pendidikan merupakan infrastruktur vital bagi kehidupan wilayah. Sesuai dengan Prinsip Dasar Manajemen Aset Infrastruktur harus dikelola dengan baik agar selalu bisa dengan baik. Resiko yang mungkin terjadi harus diperhitungkan (Suprayitno \& Soemitro, 2018). Salah satu resiko yang berakibat parah adalah resiko gempa bumi. Bangunan di Indonesia harus dipersiapkan terhadap resiko ini.

Sehingga kajian terhadap kerentanan bangunan gedung dari gempa bumi menjadi sesuatu hal yang sangat penting guna memastikan pengguna bangunan dalam kondisi aman. Kajian kerentanan bangunan pada gedung SIT Aliya Bogor menggunakan ketentuan yang tercantum pada Rapid Visual Screening (RVS) (FEMA, 2015) dan Hazus-MH MR4 (FEMA, 2003).

\section{STUDI LITELATUR}

Lutfi \& Subtoni (2017), menyatakan bangunan sekolah selayaknya harus memenuhi persyaratan teknis yang telah ditetapkan dan diatur didalam Undang- undang Bangunan Gedung No. 28 Tahun 2002 bahwa setiap gedung harus memiliki asas kemanfaatan, keselamatan, kenyamanan dan keserasian dengan lingkungannya.

Lutfi, dkk (2019), bangunan hunian sederhana harus memenuhi persyaratan teknis yang ditetapkan dalam Undang-Undang Nomor 28 Tahun 2002 tentang Bangunan Gedung. Di kota bogor ada daerah yang berpotensi tanah longsor dan pergerakan tanah yang dapat mengancam keselamatan penghuninya.

Soemitro \& Suprayitno (2018), Infrastruktur sangat penting untuk kehidupan manusia dalam bidang ekonomi, sosial, dan administrasi. Pengadaan infrastrukur membutuhkan banyak dana dan teknis dalam infrastruktur bukanlah hal yang sederhana. Dengan dana yang selalu terbatas, infrakstrukur tetap dibangun untuk memenuhi kebutuhan. Oleh karena itu, infrastruktur harus dikekola dengan baik agar infrastruktur dapat berfungsi secara ekonomis, efektif, efisien dan berkelanjutan.

Zulfiar, dkk (2014), penyebab utama kerentanan bangunan secara teknis disebabkan oleh beberapa faktor diantaranya adalah lokasi, topografi, daya dukung tanah, penggunaan material bangunan yang kurang sesuai dan bangunan yang kurang memadai dengan yang berada pada daerah gempa.

Widodo (2007), konfigurasi bangunan akan menentukan perilaku bangunan saat gempa bumi terjadi. Konfigurasi bangunan yang baik adalah bangunan yang denah dan potongannya sederhana. Sedangkan untuk bangunan yang konfigurasinya kurang baik diantaranya adalah soft story, bad mass distribution, set back dan pounding yang dapat berakibat pada tingginya kerusakan bangunan.

\section{Potensi Bencana Alam}

Bencana dapat disebabkan oleh kejadian alam (natural disaster) maupun oleh ulah manusia (man-made disaster). Faktor yang dapat menyebabkan bencana menurut United Nations International Strategy for Disaster Reduction (UN-ISDR) dapat dikelompokkan menjadi beberapa katagori, yaitu bahaya geologi (geological hazards), bahaya hidrometeorologi (hydrometeorological hazards), bahaya biologi (biological hazards), bahaya teknologi (technological hazards) dan penurunan kualitas lingkungan (environmental degradation), serta kerentanan (vulnerability) yang tinggi dari masyarakat, infrastruktur di dalam kota/kawasan yang berisiko bencana (BPBD, 2016).

\section{Gempa Bumi}

Gempa bumi (earth quake) adalah peristiwa bergetar atau bergoncangnya bumi karena pergerakan/pergeseran lapisan batuan pada kulit bumi secara tiba- tiba akibat pergerakan lempeng- lempeng tektonik. Gempa bumi yang disebabkan oleh aktivitas pergerakan lempeng tektonik disebut gempa bumi tektonik sedangkan gempa bumi yang terjadi akibat aktifitas 
gunung berapi disebut sebagai gempa bumi vulkanik. Pergerakan tiba- tiba dari lapisan batuan didalam bumi menghasilkan energi yang dipancarkan ke segala arah berupa gelombang gempa bumi atau gelombang seismik. Ketika gelombang ini mencapai permukaan bumi, getarannya dapat merusak segala sesuatu di permukaan bumi seperti bangunan dan infrastruktur lainnya sehingga dapat menimbulkan korban jiwa dan harta benda (Sunarjo, Gunawan \& Pribadi, 2012). Peta Sumber dan Bahaya Gempa Bumi Indonesia tahun 2017 disampaikan pada Gambar 1.

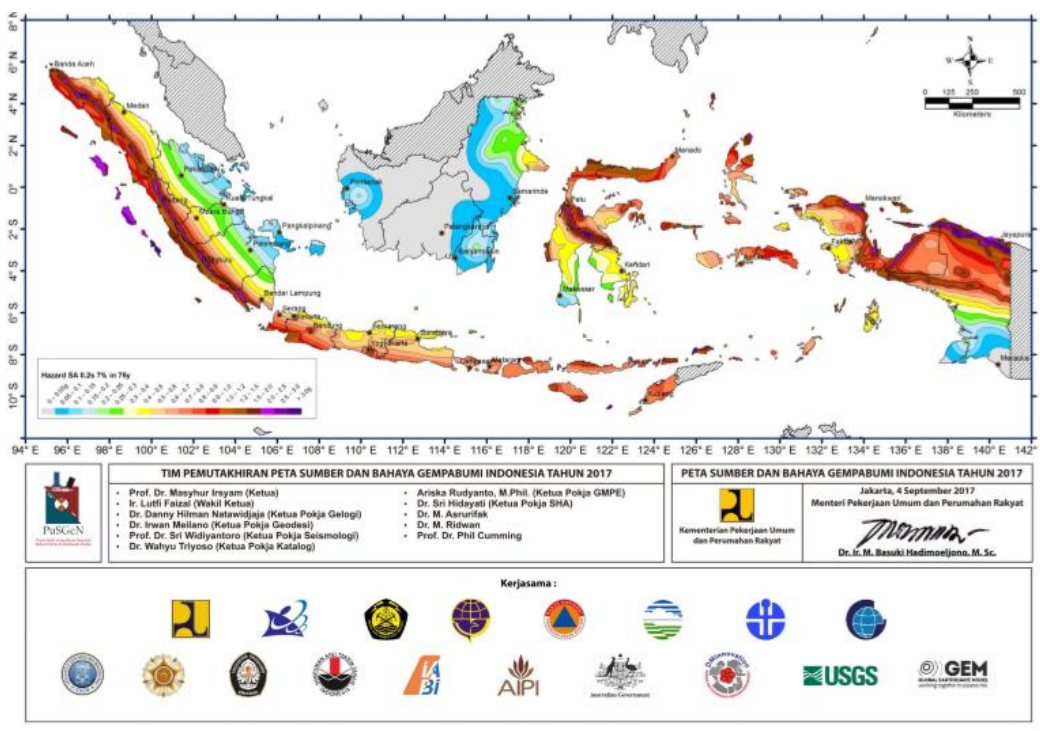

Gambar 1. Peta Sumber dan Bahaya Gempa Bumi Indonesia tahun 2017 (Sumber : Pusat Studi Gempa Nasional, 2017)

\section{METODE PENELITIAN}

Penelitian mengenai kerentanan bangunan gedung sekolah ini dilakukan di SIT Aliya Kota Bogor pada bulan November tahun 2019 - Februari tahun 2020, yang berlamat di Jl. Gardu Raya, RT.03/RW.11, Bubulak, Kec. Bogor Barat, Kota Bogor, Jawa Barat 16115 dengan koordinat Latitude : -6.57084 ; Longitude: 106.7500. Metode yang digunakan dalam penelitian ini adalah perbandingan antara Metode Rapid Visual Screening (RVS) (FEMA P-154 tahun 2015) dan Hazus-MH MR4 (FEMA, 2003). Adapun tahapan dari masing-masing metode sebagai berikut :

\section{Rapid Visual Screening (RVS)}

Pada Rapid Visual Screening (RVS) ini langkah awal untuk melakukan evaluasi kerentanan bangunan sekolah terhadap gempa bumi adalah survei lapangan. Melakukan pengamatan secara langsung pada bangunan dan didokumentasikan berupa foto untuk informasi data selanjutnya. Adapun tahapannya sebagai berikut.

1. Data tanah diasumsikan jenis tanah sedang (tipe D) sesuai dengan FEMA P-154 tahun 2015 karena pada penelitian ini tidak dilakukan penyelidikan tanah.

2. Koordinat bangunan yang berada di SIT Aliya Bogor didapatkan dari aplikasi Coordinator dengan berbasis Global Positioning System (GPS) seperti pada Tabel 1. 
Tabel 1. Koordinat Bangunan

\begin{tabular}{clrc}
\hline \multirow{2}{*}{ No. } & \multicolumn{2}{|c}{ Nama Gedung } & \multicolumn{2}{c}{ Koordinat } \\
\cline { 3 - 4 } & & Latitude & Longitude \\
\hline 1 & Gd. Abu Bakar Siddiq & $-6,57078$ & 106,75018 \\
2 & Gd. Umar A & $-6,57075$ & 106,74998 \\
3 & Gd. Umar B & $-6,57063$ & 106,74995 \\
4 & Gd. Ali & $-6,57074$ & 106,75012 \\
5 & Gd. Usman A & $-6,57051$ & 106,74990 \\
6 & Gd. Usman B & $-6,57038$ & 106,74980 \\
\hline
\end{tabular}

3. Hasil $S_{S}$ dan $S_{1}$ berdasarkan Koordinat Bangunan di dapat dari aplikasi Desain Spektra Indonesia (Puskim, 2011), sepertipada Tabel 2. Dan Gambar 2. dibawah ini.

Tabel 2.Nilai Desain Spectra

\begin{tabular}{ccccc}
\hline \multirow{2}{*}{ No. } & \multicolumn{2}{c}{ Koordinat } & \multirow{2}{*}{$\mathbf{S}_{\mathbf{s}}$} & $\mathbf{S}_{\mathbf{1}}$ \\
\cline { 2 - 4 } & Latitude & Longitude & & \\
\hline 1 & $-6,57078$ & 106,75018 & 0,87 & 0,35 \\
2 & $-6,57075$ & 106,74998 & 0,87 & 0,35 \\
3 & $-6,57063$ & 106,74995 & 0,87 & 0,35 \\
4 & $-6,57074$ & 106,75012 & 0,87 & 0,35 \\
5 & $-6,57051$ & 106,74990 & 0,87 & 0,35 \\
6 & $-6,57038$ & 106,74980 & 0,87 & 0,35 \\
\hline
\end{tabular}

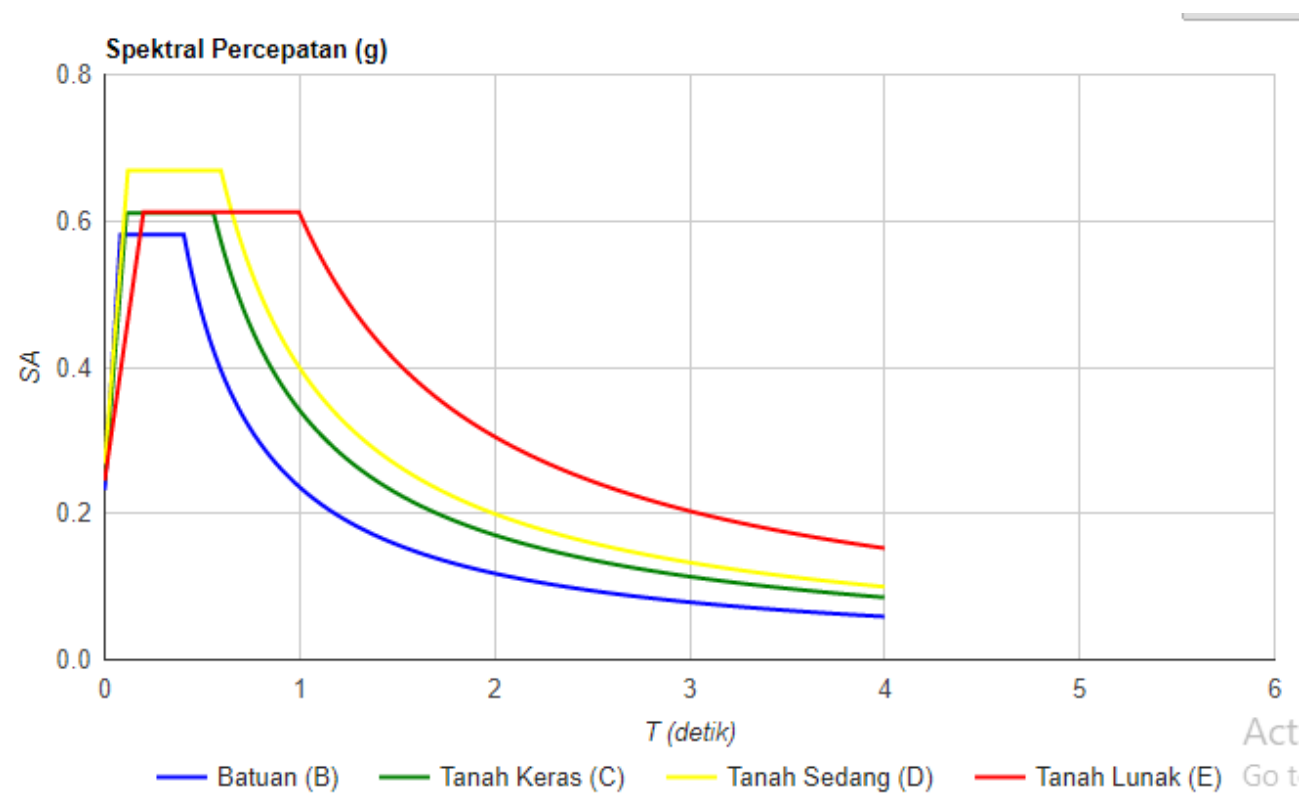

Gambar 2. Respon Spectrum

Dari data diatas maka dihasilkan nilai rata-rata $S_{S}=0,871$ dan nilai $S_{1}=0,354$. Dari hasil rata-rata seperti itu,maka dipilih formulir RVS dengan level moderarately high seismicity.

4. Setelah melakukan survey lapangan dan mengetahui nilai $S_{\mathrm{s}}$ dan $S_{1}$ dari masing-masing koordinat bangunan sekolah, dan untuk mengetahui kerentanan suatu bangunan dengan menggunakan metode RVS dengan acuan FEMA P-154 2015, maka menggunakan 
formulir Moderately High Seisemicity. Berikut langkah - langkah untuk mengisi formulir RVS pada Gambar 3. yaitu:

a. Memverifikasi dan memperbarui informasi identifikasi bangunan;

b. Berjalan disekitar gedung untuk mengidentifikasi jumlah cerita dan bentuk, dan membuat sketsa rencana dan tampilan ketinggian pada Formulir Pengumpulan Data;

c. Memotret bangunan;

d. Menentukan dan mendokumentasikan hunian;

e. Mengkaji jenis tanah dan bahaya geologis, sebagaimana diidentifikasi selama proses perencanaan pra-lapangan;

f. Mengidentifikasi masalah kedekatan, membangun penyimpangan, dan potensi bahaya jatuh eksterior;

g. Menambahkan komentar apa pun tentang kondisi atau keadaan yang tidak biasa yang dapat memengaruhi penyaringan;

h. Mengidentifikasi bahan bangunan, sistem pembawa beban gravitasi, dan sistem penahan gaya gempa untuk mengidentifikasi Tipe Bangunan FEMA (jika memungkinkan, untuk memfasilitasi proses ini) dan melingkari Skor Dasar pada Formulir Pengumpulan Data;

i. Mengitari atribut kinerja seismik yang sesuai Pengubah Skor (mis., Penyimpangan, tanggal desain, dan jenis tanah) pada Formulir Pengumpulan Data

j. Menentukan Skor Level 1 Akhir, SL1 (dengan menyesuaikan Skor Dasar dari Langkah 8 dengan Pengubah Skor yang diidentifikasi pada Langkah 9); dan

k. Mengisi bagian ringkasan di bagian bawah formulir (mis., Tingkat Tinjauan, Bahaya Lain dan Tindakan yang Diperlukan).

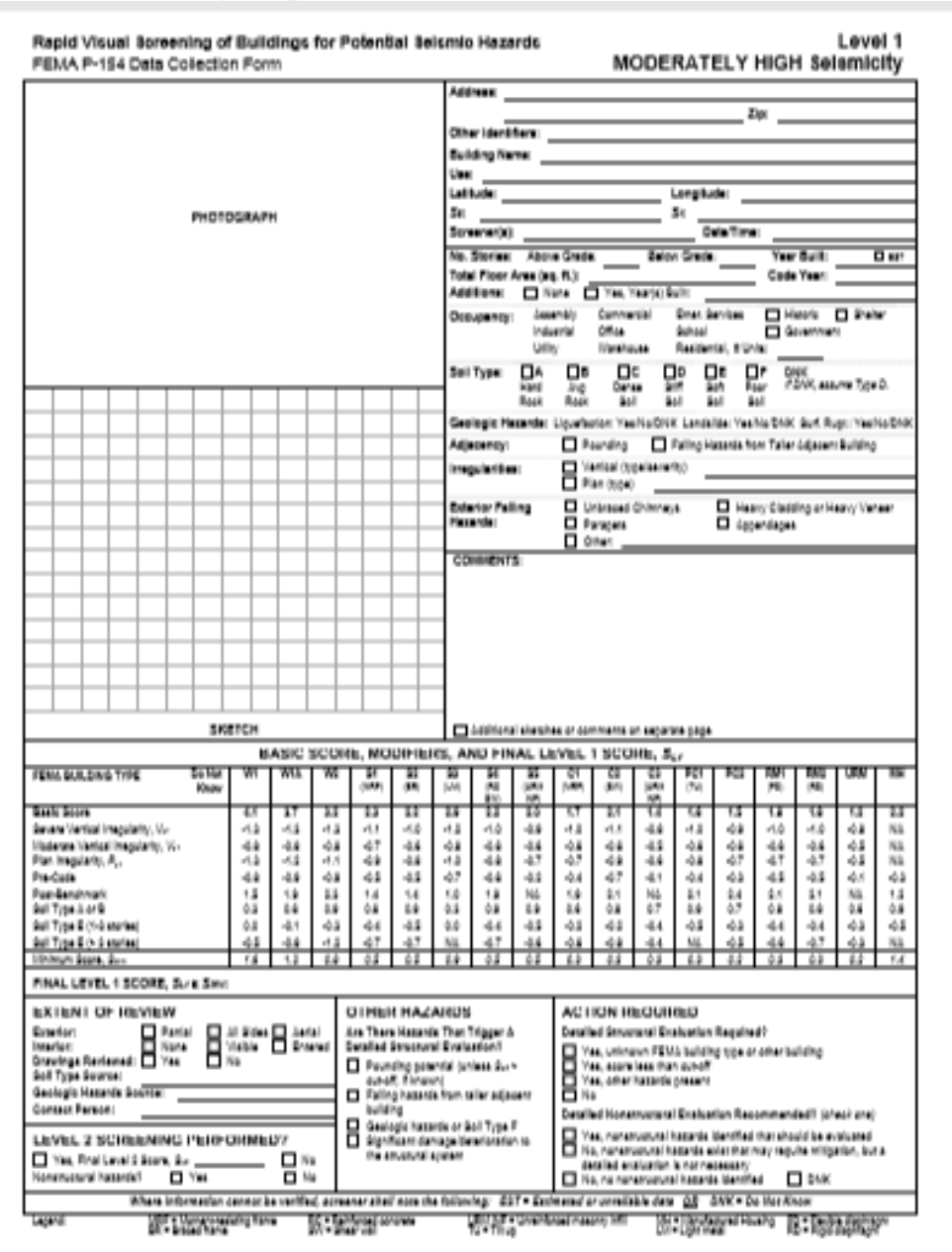


Gambar 3. Formulir RVS

(Sumber : FEMA P-145 tahun 2015)

\section{Metode Hazus}

Adapun langkah-langkah dalam mendapatkan tingkat kerusakan pada bangunan sekolah dengan Metode Hazusadalah sebagai berikut.

1. Tipe Bangunan tersusun atas material kontruksi rangka beton yang masuk dalam katagori C1M (Bangunan rangka beton yang menahan momen) sesuai degan Tabel 5.1 dalam HAZUS-MH MR4(FEMA, 2003).

2. Menentukan Seismic Design Level menggunakan moderete - code seismic design level, karena menyamakan dengan RVS.

3. Respon Curve hubungan antara spectral displacement, $\mathrm{Sa}$ (sb.x) dan spectral accelation, $\mathrm{Sd}$ (sb.y). carispectral accelation pada $\mathrm{t}=0,3$ detik dan 1 detik. Spectral displacement didapatkan dengan menggunakan aplikasi Desain Spketra Indonesia (Puskim, 2011), sehingga mendapatkan hasil seperti Tabel 3 berikut ini. 
Tabel 3.Hasil Sa dan Sd

\begin{tabular}{ccc}
\hline $\mathrm{T}$ & $\mathrm{Sa}$ & $\mathrm{Sd}$ \\
\hline 0 & 0,232 & 0 \\
0,2 & 0,334 & 0,130928 \\
0,3 & 0,293 & 0,258426 \\
1 & 0,157 & 1,5386 \\
\hline
\end{tabular}

(Sumber: Puskim, 2011)

\section{ANALISIS PENELITIAN}

\section{Rapid Visual Screening (RVS)}

Setelah survei lapangan selesai, selanjutnyan dilakukan penilaian kerentanan bangunan sekolah SIT Aliya Bogor degan mendapatkan nilai akhir yaitu final score. Nilai final score merupakan kemungkinan terjadinya keruntuhan pada bangunan jika mengalami gempa. Hasil penelitian bangunan SIT Aliya Bogor dengan tipe bangunan $\mathrm{C} 1$ memiliki minimum score sebesar 0,3. Berikut ini hasil evaluasi bangunan sekolah SIT Aliya Bogor dengan menggunakan formulir RVS pada Tabel 4. dan Gambar 4. sebagai berikut.
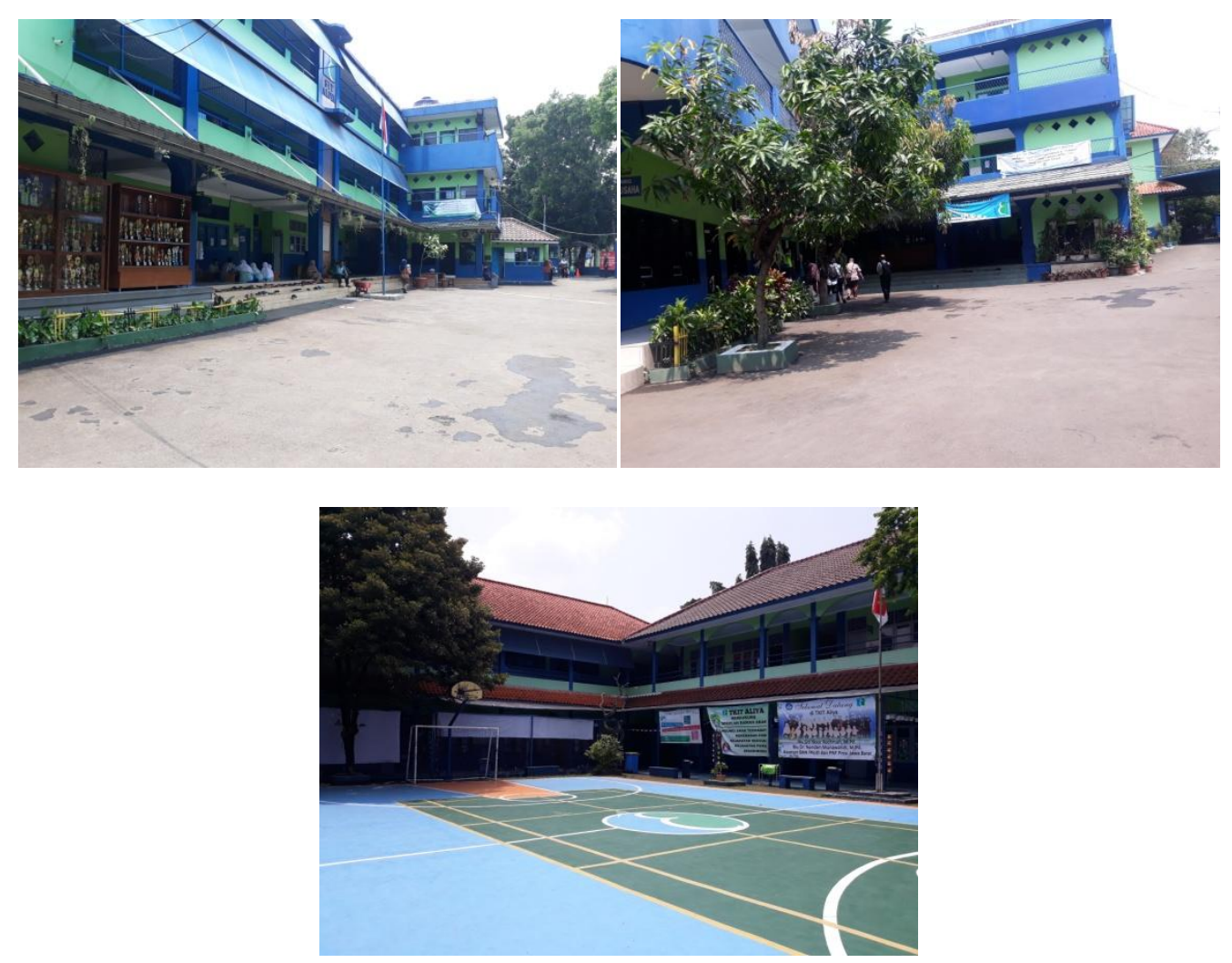

Gambar 4. Bangunan Sekolah SIT Aliya Bogor (Sumber: Dokumetasi Pribadi) 
Tabel 4.Hasil Final Score Bangunan Sekolah berdasarkan RVS

\begin{tabular}{|c|c|c|c|c|c|c|c|c|c|c|c|}
\hline$\dot{\mathrm{z}}$ & 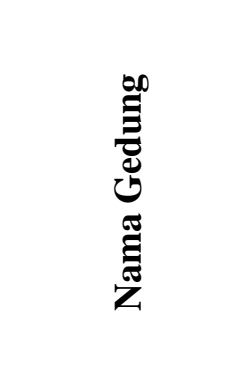 & 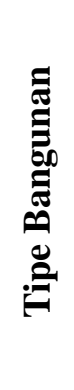 & 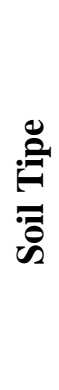 & 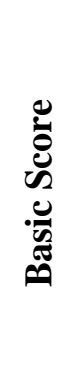 & 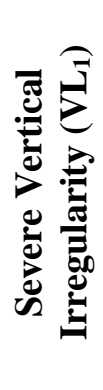 & 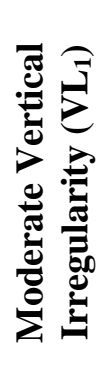 & 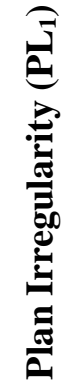 & 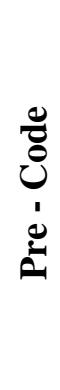 & 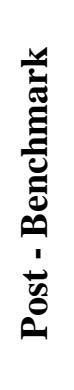 & 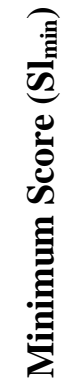 & $\begin{array}{l}\mathscr{2} \\
\stackrel{\bar{E}}{\bar{Z}} \\
\bar{z}\end{array}$ \\
\hline 1 & Gd. Abu Bakar & $\mathrm{C} 1$ & $\mathrm{D}$ & 1,7 & - & $-0,6$ & $-0,7$ & - & 1,9 & 0,3 & 2,3 \\
\hline 2 & Gd. Umar A & $\mathrm{C} 1$ & $\mathrm{D}$ & 1,7 & - & - & - & - & 1,9 & 0,3 & 3,6 \\
\hline 3 & Gd. Umar B & $\mathrm{C} 1$ & $\mathrm{D}$ & 1,7 & - & $-0,6$ & - & - & 1,9 & 0,3 & 3 \\
\hline 4 & Gd. Ali & $\mathrm{C} 1$ & $\mathrm{D}$ & 1,7 & - & $-0,6$ & - & - & 1,9 & 0,3 & 3 \\
\hline 5 & Gd. Usman A & $\mathrm{C} 1$ & $\mathrm{D}$ & 1,7 & - & - & - & - & 1,9 & 0,3 & 3,6 \\
\hline 6 & Gd. Usman B & $\mathrm{C} 1$ & $\mathrm{D}$ & 1,7 & - & $-0,6$ & - & - & 1,9 & 0,3 & 3 \\
\hline
\end{tabular}

Dari Tabel 4. menunjukan gedung di sekolah SIT Aliya Bogor yang memiliki final score paling besar adalah gedung Umar A, dan Usman A dengan final score 3,6. Sedangkan gedung yang memiliki final score paling rendah aladah gedung Abu Bakar Siddiq dengan final score 2,3 .

Berdasarkan hasil final score yang sudah didapat, langkah selanjutnya adalah mengalanisis kerentanan bangunan SIT Aliya Bogor sebagai berikut pada Tabel 5 .

Tabel 5. Hasil Analisis Kerentanan Bangunan Sekolah

\begin{tabular}{llcccc}
\hline No. & Nama Gedung & Nilai S & $\mathbf{1 0}^{\text {SL1 }}$ & $\mathbf{1 / 1 0}^{\text {SL1 }}$ & $\begin{array}{c}\text { Potensi } \\
\text { Kerentanan } \\
(\boldsymbol{\%})\end{array}$ \\
\hline 1 & Gd. Abu Bakar & 2,3 & 199,526 & 0,00501 & 0,501 \\
2 & Gd. Umar A & 3,6 & 3981,072 & 0,00025 & 0,025 \\
3 & Gd. Umar B & 3 & 1000,000 & 0,00100 & 0,100 \\
4 & Gd. Ali & 3 & 1000,000 & 0,00100 & 0,100 \\
5 & Gd. Usman A & 3,6 & 3981,072 & 0,00025 & 0,025 \\
6 & Gd. Usman B & 3 & 1000,000 & 0,00100 & 0,100 \\
\hline & Rata - rata & 3,083 & 1211,528 & 0,00083 & 0,083 \\
\hline
\end{tabular}

Dari tabel diatas maka hasil analisis bangunan sekolah SIT Aliya Bogor dapat dijabarkan sebagai berikut ini.

1. Gedung Abu Bakar mendapatkan nilas S sebesar 2,3 dan memiliki potensi kerentanan sebesar $0,501 \%$.

2. Gedung Umar A mendapatkan nilas $\mathrm{S}$ sebesar 3,6 dan memiliki potensi kerentanan sebesar $0,025 \%$.

3. Gedung Umar B mendapatkan nilas S sebesar 3 dan memiliki potensi kerentanan sebesar $0,100 \%$.

4. Gedung Ali mendapatkan nilas $\mathrm{S}$ sebesar 3 dan memiliki potensi kerentanan sebesar $0,100 \%$. 
5. Gedung Usman A mendapatkan nilas $\mathrm{S}$ sebesar 3,6 dan memiliki potensi kerentanan sebesar $0,025 \%$.

6. Gedung Usman B mendapatkan nilas S sebesar 3 dan memiliki potensi kerentanan sebesar $0,100 \%$.

Dari keseluruhan gerdung yang berada di SIT Aliya Bogor, maka SIT Aliya Bogor mendapatkan nilai rata-rata sebesar 3,083 dan memiliki potensi kerentanan sebesar 0,083\%

\section{Metode Hazus}

Sedangkan pada Metode Hazus setelah nilai spectral displacement, Sa (sb.x) dan spectral accelation, $\mathrm{Sd}$ (sb.y) didapat, maka langkah selanjutnya seperti dibawah ini.

1. Membuat Respon Curve

Respon curve didapat dari data pada tabel 3, maka akan diperoleh respon curve sebagai berikut.

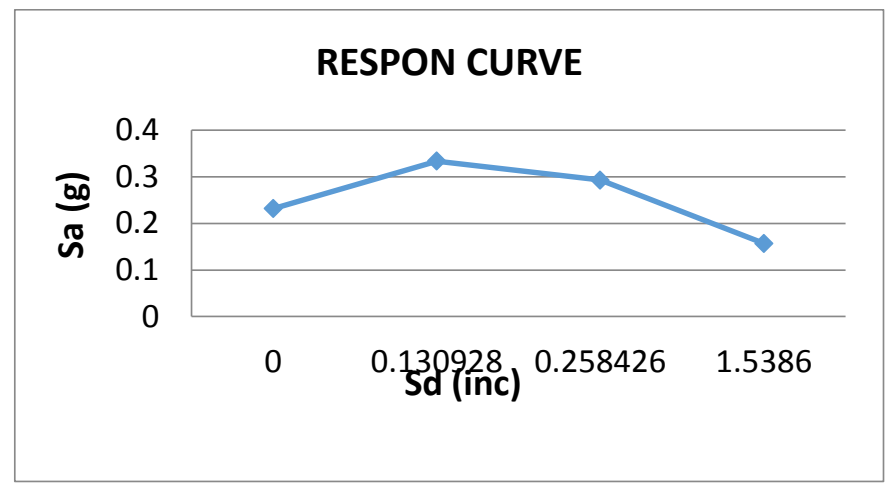

Gambar 5. Respon Curve

2. Membuat Capasity Curve

Parameter capacity curve yang diperoleh sesuai pada tabel 5.7b HAZUS-MH MR4 (FEMA 2003 ) untuk tipe bangunan C1M dengan moderete - code design level sebagai berikut:

a. Yieldcapasity point $(\mathrm{Dy}, \mathrm{Ay})=(0.20,0.125)$

b. Ultimate capacity point $(\mathrm{Du}, \mathrm{Au})=(3.52,0.375$

Maka diperoleh capasity curve sebagai berikut :

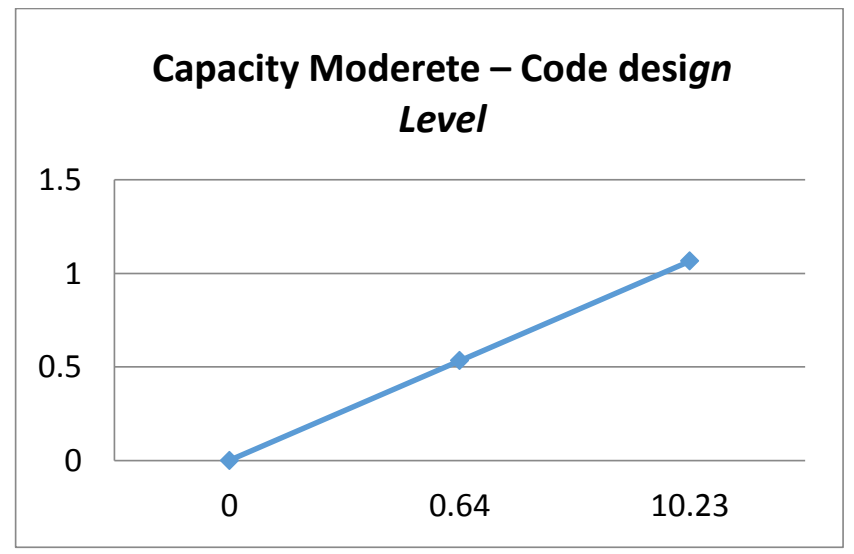

Gambar 6. Capasity Curve

3. Perpotongan Respon Curve Dan Capasity Curve

Perpotongan antara respon curve dan capasity curve didapatkan setelah kedua curve dijadikan satu. 


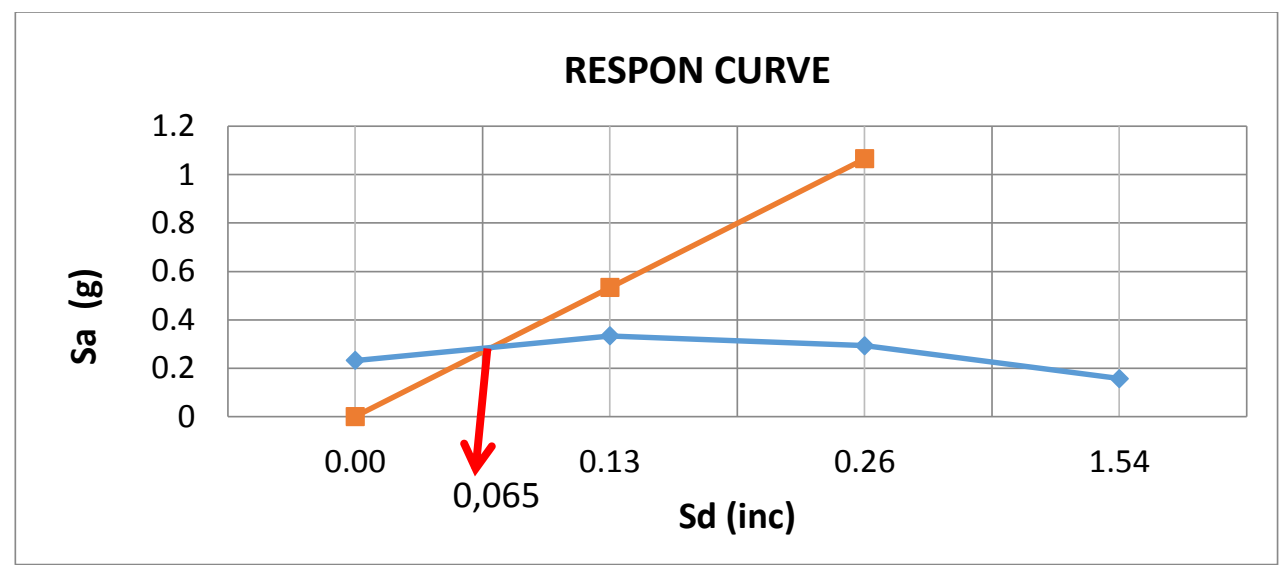

Gambar 7. Perpotongan Respon Curve dan Capasity Curve

Pada perpotongan kedua curve diatas menghasil nilai Sd sebesar 0.065

4. Menghitung Probabilitas Kerusakan

Parameter probabilitas kerusakan yang diperoleh sesuai pada tabel 5.9b HAZUS-MH MR4 (FEMA 2003) untuk tipe bangunan $\mathrm{C} 1 \mathrm{M}$ dengan moderete - code design levelberdasarkan nilai $\Phi$ (Saputra, 2019) pada slight 0,0114, moderate sebesar 0,008, extensive sebesar 0,00000166 dan complete sebesar 0,00000064, sehingga didapatkan nilai probabilitas kerusakan bangunan pada Tabel 6 . sebagai berikut:

Tabel 6. Probabilitas Kerusahan Gedung

\begin{tabular}{lccccc}
\hline \multicolumn{1}{c}{ Rumus } & Slight & Moderate & Extensive & Complete & None \\
\hline $\mathrm{Sd}$ & 0,065 & 0,065 & 0,065 & 0,065 & \\
$\mathrm{~S}_{\mathrm{ds}}$ & 0,9 & 1,56 & 4,2 & 10,8 & \\
$\beta_{\mathrm{ds}}$ & 0,89 & 0,9 & 0,9 & 0,89 & \\
$\mathrm{Sd} / \mathrm{S}_{\mathrm{ds}}$ & 0,072 & 0,042 & 0,015 & 0,006 & \\
$\ln \left(\mathrm{Sd} / \mathrm{S}_{\mathrm{ds}}\right)$ & $-2,628$ & $-3,178$ & $-4,168$ & $-5,113$ & \\
$\left(\ln \left(\mathrm{Sd} / \mathrm{S}_{\mathrm{ds}}\right)\right) / \beta_{\mathrm{ds}}$ & $-2,953$ & $-3,531$ & $-4,632$ & $-5,745$ & \\
$\Phi(\ln (\mathrm{Sd} / \mathrm{S} \mathrm{ds})) / \beta_{\mathrm{ds}}$ & 0,0337 & 0,0282 & 0,0000 & 0,0000 & \\
\multicolumn{1}{c}{$\%$} & 3,3662 & 2,8249 & 0,0008 & 0,0004 & 93,8077 \\
\hline
\end{tabular}




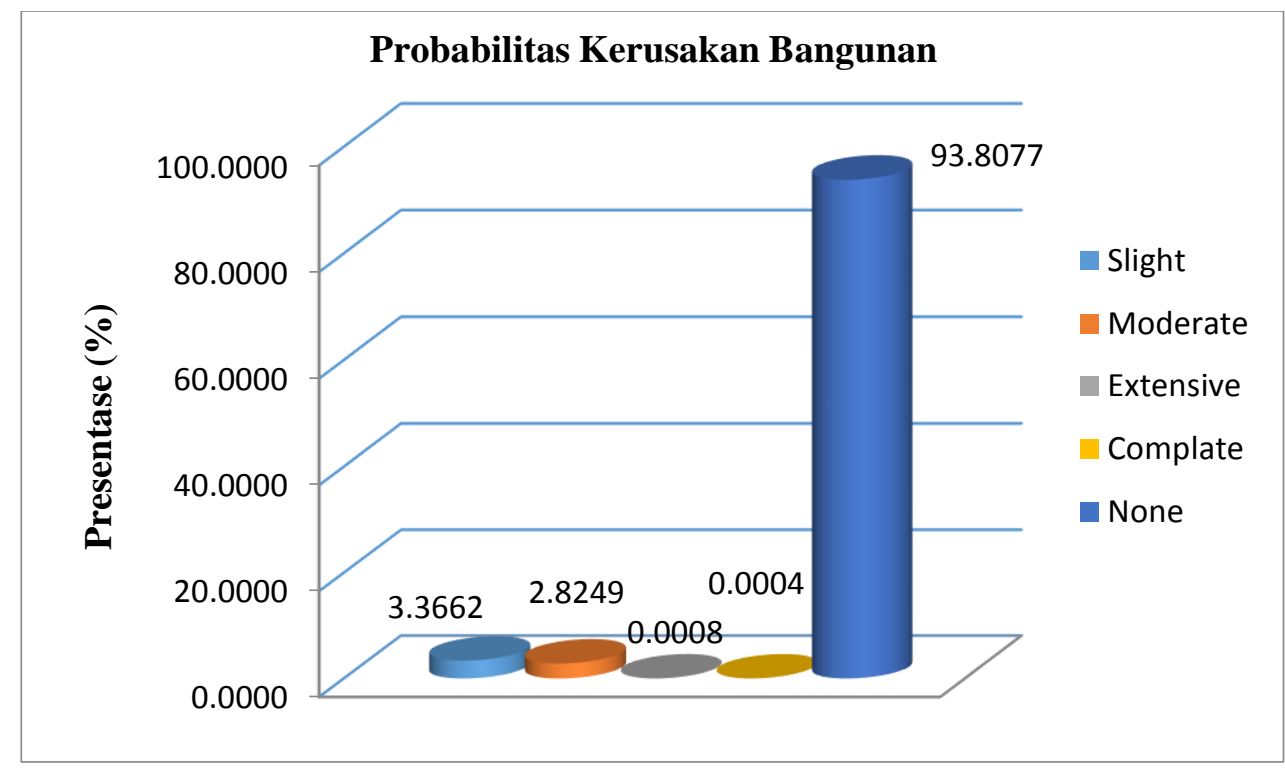

Gambar 8. Probabilitas Kerusakan Bangunan

Dapat dilihat dari grafik diatas SIT Aliya Bogor memiliki probabilits kerusakan bangunan sebesar 6,1923\% dan bangunan yang tidak roboh atau none sebesar 93,8077\%. hasil tersebut merupakan acuan bahwa bangunan yang beradapada SIT Aliya Bogor aman terhadap gempa.

\section{KESIMPULAN}

Berikut adalah kesimpulan dari sekolah SIT Aliya Bogor berdasarkah hasil analisis yang telah dilakukan:

1. Hasil analisis Rapid Visual Screening (RVS) Sekolah SIT Aliya Bogor memiliki bangunan rentan terhadap gempa karena adanya vertical irregularity dan plan irregularity yang mempengaruhi basic score.

2. Secara keseluruhan bangunan memiliki potensi kerentanan bangunan terhadap gempa bumi sebesar $0,083 \%$. Dengan gedung yang memiliki final score paling besar adalah gedung Umar A, dan Usman A sebesar 3,6 dan gedung yang memiliki final score paling rendah adalah gedung Abu Bakar Siddiq dengan final score 2,3.

3. Hasil analisis kerusakan probabilitas kerusakan dengan Metode Hazus dengan memperoleh nilai cumulative probability menunjukan bahwa bangunan mengalami tingkat kerusakan slight sebesar 3,3662\%, kerusakan moderate sebesar 2,8249\%, extensive sebersar $0,0008 \%$ dan complate sebesar $0,0004 \%$, sehingga nilai total sebesar $6,1923 \%$.

4. Bangunan sekolah SIT Aliya Bogor yang tidak mengalami kerusakan sebesar $99,917 \%$ berdasarkan hasil Rapid Visual Screening (RVS) dan 93,8077 \% berdasarkan Metode Hazus.

\section{DAFTAR PUSTAKA}

BPBD (2016). "Mitigasi Bencana Kota Bogor". Badan Penanggulangan Bencana Daerah. https://mitigasibencana.bpbd.kotabogor.go.id/index.php/edukasi/detail/Potensi Ancaman-Bencana-13.Diakses 21 November 2019.

BPBD (2019). "Riwayat Kejadian Bencana". Badan Penanggulangan Bencana Daerah. https://bpbd.kotabogor.go.id/riwayat. Diakses 29 Oktober 2019.

FEMA (2003). HAZUS-MH MR4 Technical Manual. Federal Emergency Management Agency. Washington, DC, U.S.A. 
FEMA (2015). Rapid Visual Screening of Buildings for Potential Seismic Hazards: A Handbook (Third Edition), FEMA P-154. Federal Emergency Management Agency. Washington, DC, U.S.A.

Lutfi, M. \& Subtoni. (2017). "Kajian Struktur Bangunan Akibat Penurunan Mutu Beton Pada Kolom Terpasang (Studi Kasus: SDN 01 Cikaret Kabupaten Bogor)". Jurnal Rekayasa Sipil ASTONJADRO. Vol. 6, No. 2, Desember 2017, Hal: 115-129.

Lutfi, M., Heryansyah, A., Hendrawati M., Jaya, R.P. \& Irawan, R.N. (2019). “Assessment of safety performance level on simple urban residential building:Case study at Bogor City Indonesia". Proceedings of 3rd National Conference on Wind \& Earthquake Engineering and 1st International Seminar on Sustainable Construction Engineering (NCWE \& ISSCE). Vol. 712, No. 1, Juli 2019, Hal: 9-15.

Pusat Studi Gempa Nasional (2017). Peta Sumber dan Bahaya Gempa Indonesia Tahun 2017. Pusat Penelitian dan Pengembangan Perumahan dan Permukiman, Badan Penelitian dan Pengembangan Kementerian Pekerjaan Umum dan Perumahan Rakyat. Bandung.

Puskim. (2011). "Desain Indonesia". http://puskim.pu.go.id/Aplikasi/desain_spektra_indonesia_2011/. Diakses 12 Januari 2020.

Saputra, Ardha Aga (2019). Evaluasi Kinerja dan Probabilitas Kerusakan Seismik Gedung Laboratorium dengan Analisis Pushover dan Metode Hazus. Skripsi. Universitas Islam Indonesia.

Sunarjo, Gunawan, M.T., \& Pibadi, S. (2012). Gempa Bumi. Badan Meteorologi Klimatologi dan Geofisika. Jakarta.

Suprayitno, H. \& Soemitro, R.A.A. (2018). "Preliminary Reflexion on Basic Principle of Infrastructure Asset Management". Jurnal Manajemen Aset Infrastruktur \& Fasilitas, Vol. 2, No. 1, Maret 2018, Hal: 1-9.

Widodo. (2007).“Kerusakan Bangunan pada Gempa Yogyakarta 27 Mei 2006 : Akibat Kebelumjelasan Code, Sosialisasai Atau Pelaksanaan”. Proseding Seminar Himpunan Ahli Kontruksi Indonesia 2007, Jakarta, 21-22 Agustus, 1-17.

Zulfiar, M. H., Tamin, R. Z., Pribadi K. S., \& Imran, I. (2014).“Identifikasi faktor Dominan Penyebab Kerentanan Bangunan di Daerah Rawan Gempa Provinsi Sumatra Barat".Jurnal Ilmiah Semesta Teknika.Vol. 17, No. 2, 116-125. 